Historic, Archive Document

Do not assume content reflects current scientific knowledge, policies, or practices. 



\section{Chinese Cinnamon Vines}

Cinnamon Vines - from the Oriental land are the most charming of climbers, and will quickly surround your arbor, windows and veranda with a wonderful profusion of lovely vines covered with handsome, glossy heart-shaped leaves and sweet-scented flowers making them all

\section{FERFEGT BOWERS OF BEAUTY}

Perfectly Hardy, thriving everywhere in sun or shade, and once planted will grow a lifetime and be a constant delight to the whole family. They come from China-the land of wonders. No words can describe their beauty and marvelous sweet perfume.

\section{IT ALWAYS PAYS TO MAKE HOME BEAUTIFUL}

No Home is complete without these wonderous vines. No one should miss this chance of planting them. They will grow 30 feet in a single season. We offer you genuine Headquarters Stock direct from the largest grower of Cinnamon Vines in the world-as follows:-

Five Selected Tubers or Roots-carefully packed, boxed and postpaid for 25 cts. Ten for 50 cts. Twenty for $\$ 1.00$. Torder at once. Roots will keep perfectly. Plant any time from earliest spring up to July 15 th.
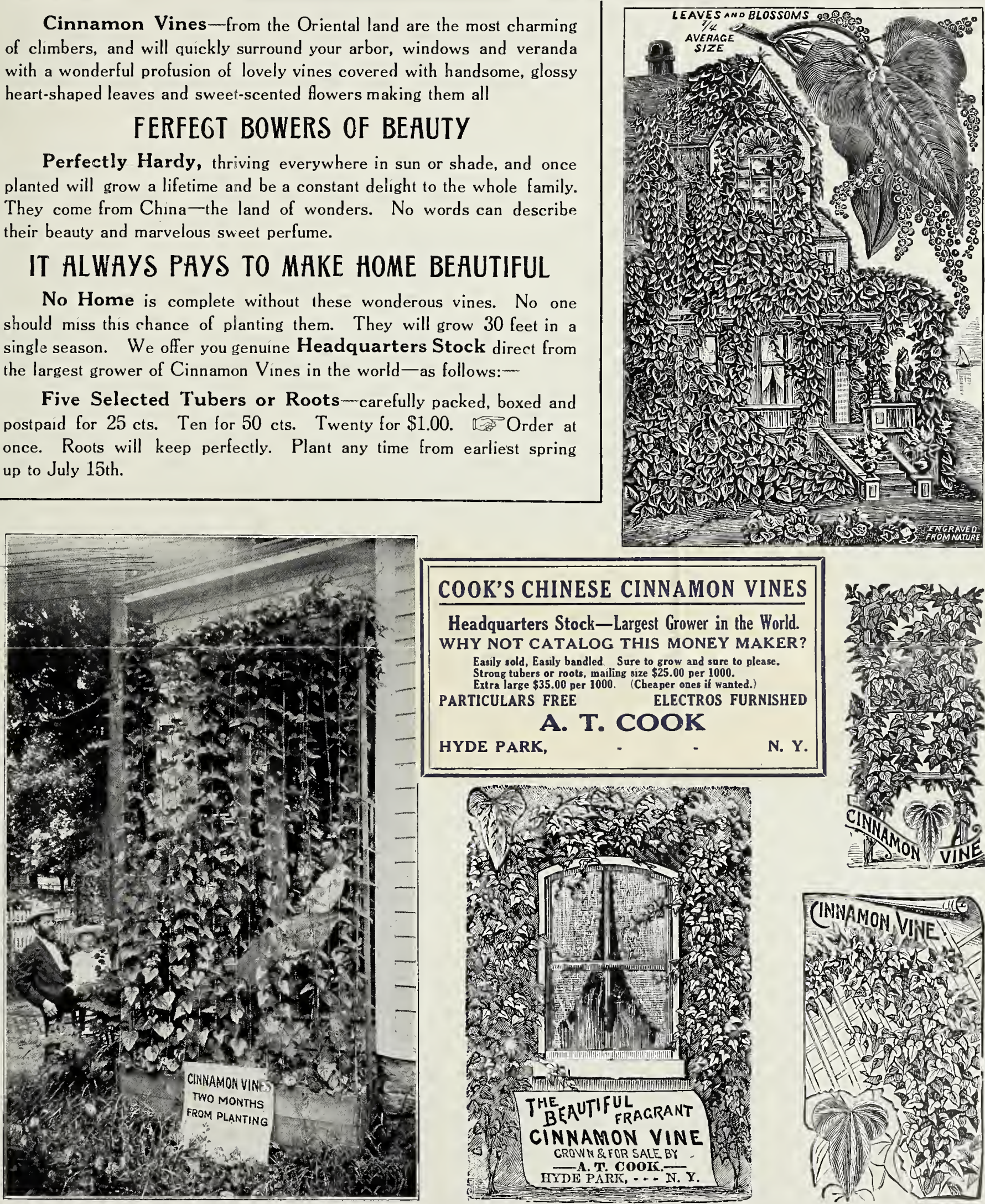

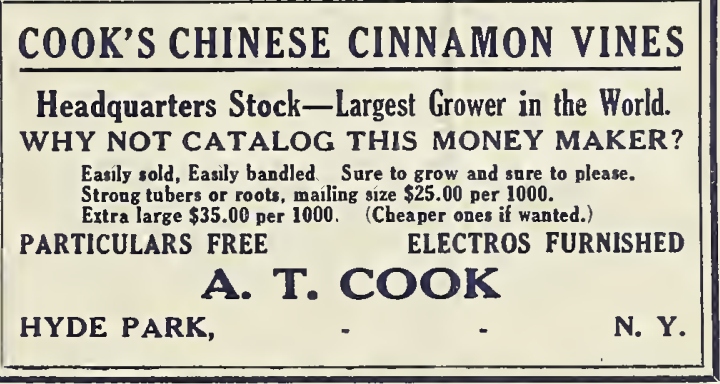

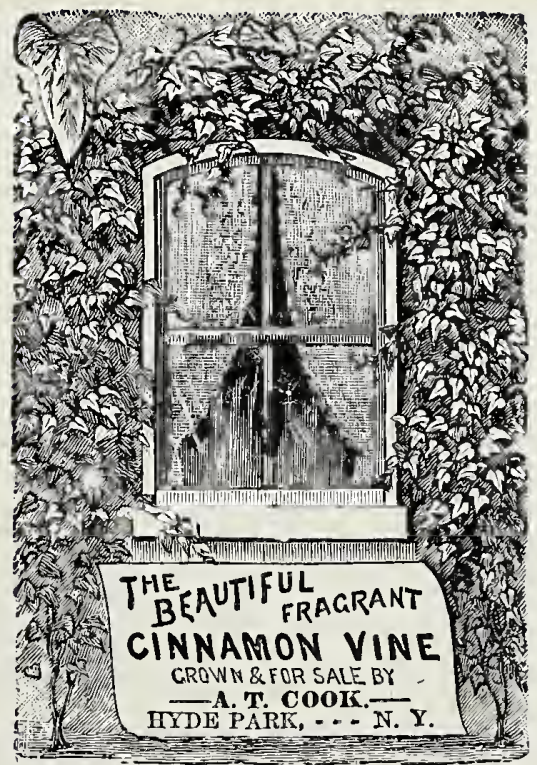

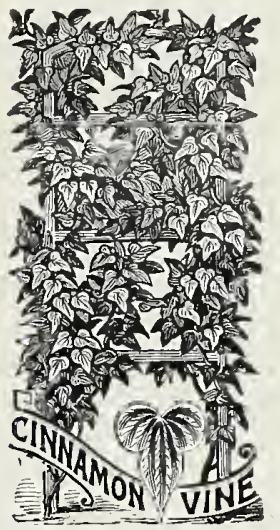

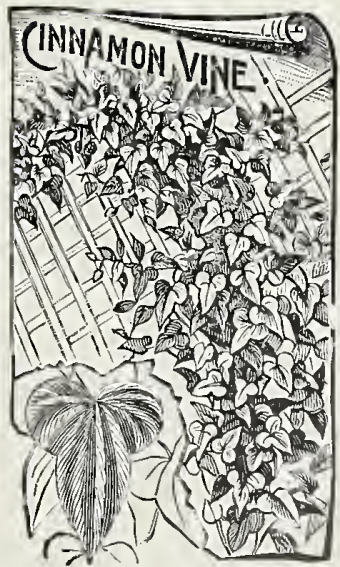


